\title{
Acute Effects of Insulin-like Growth Factor I on Glucose and Amino Acid Metabolism in the Awake Fasted Rat \\ Comparison with Insulin
}

Ralph Jacob, Eugene Barrett, Gerd Plewe, Katherine D. Fagin, and Robert S. Sherwin

Departments of Medicine and Pediatrics, Yale University School of Medicine, New Haven, Connecticut 06510

\begin{abstract}
To elucidate the acute metabolic actions of insulin-like growth factor I (IGF-I), we administered a primed $(250 \mu \mathrm{g} / \mathrm{kg})$, continuous $(5 \mu \mathrm{g} / \mathrm{kg} \cdot \mathrm{min})$ infusion of human recombinant $(\mathrm{Thr}$ 59) IGF-I or saline to awake, chronically catheterized 24-h fasted rats for $90 \mathrm{~min}$. IGF-I was also infused while maintaining euglycemia (glucose clamp technique) and its effects were compared to those of insulin. IGF-I infusion caused a twofold rise in IGF-I levels and a 75-85\% decrease in plasma insulin. When IGF-I alone was given, plasma glucose fell by 30-40 $\mathrm{mg} / \mathrm{dl}(P<0.005)$ due to a transient twofold increase $(P$ $<0.05)$ in glucose uptake; hepatic glucose production and plasma FFA levels remained unchanged. IGF-I infusion with maintenance of euglycemia produced a sustained rise in glucose uptake and a marked stimulation of $\left[3-{ }^{3} \mathrm{H}\right]$ glucose incorporation into tissue glycogen, but still failed to suppress glucose production and FFA levels. IGF-I also produced a generalized $30-40 \%$ reduction in plasma amino acids, regardless of whether or not hypoglycemia was prevented. This was associated with a decrease in leucine flux and a decline in the incorporation of $\left[1-{ }^{14} \mathrm{C}\right]$ leucine into muscle and liver protein $(P<0.05)$. When insulin was infused in a dosage that mimicked the rise in glucose uptake seen with IGF-I, nearly identical changes in amino acid metabolism occurred. However, insulin suppressed glucose production by $65 \%$ and FFA levels by 40\% $(P<0.001)$. Furthermore, insulin was less effective than IGF-I in promoting glycogen synthesis.

We conclude that (a) IGF-I produces hypoglycemia by selectively enhancing glucose uptake; (b) IGF-I is relatively ineffective in suppressing hepatic glucose production or FFA levels; and (c) IGF-I, like insulin, lowers circulating amino acids by reducing protein breakdown rather than by stimulating protein synthesis. Thus, IGF-I's metabolic actions in fasted rats are readily distinguished from insulin.
\end{abstract}

\section{Introduction}

Insulin-like growth factor I (IGF-I), ${ }^{1}$ the putative mediator of growth hormone's somatotrophic actions in vivo (1), has long

Dr. Fagan's present address is AMGen Biologicals, Thousand Oaks, CA 91320 .

Received for publication 27 June 1988 and in revised form 11 November 1988 .

1. Abbreviations used in this paper: IGF-I, insulin-like growth factor I; KIC, $\alpha$-ketoisocaproate.

J. Clin. Invest.

(c) The American Society for Clinical Investigation, Inc.

$0021-9738 / 89 / 05 / 1717 / 07 \quad \$ 2.00$

Volume 83, May 1989, 1717-1723 been recognized to exert metabolic actions in vitro that closely resemble those of insulin. For example, IGF-I can mimic insulin's capacity to promote glucose uptake and metabolism in isolated muscle and adipose tissue (2-5), stimulate glycogen synthesis in rat heart and diaphragm muscle $(2,5)$, accelerate amino acid transport in fibroblasts (6), and increase net protein synthesis in cartilage (7). IGF-I's metabolic effects in vitro occur at much lower concentrations in muscle than in adipose tissue (3-6); IGF-I appears to act through its own receptor in muscle, but only through its capacity to bind to the insulin receptor of adipocytes (8-11).

The limited availability of IGF-I in purified form has, until recently, prevented a systematic examination of IGF-I's effects on body fuel metabolism under in vivo conditions. Using partially purified preparations of IGF-I, early studies demonstrated a plasma glucose lowering effect that was particularly evident in hypophysectomized and adrenalectomized animals $(12,13)$. More recently, Froesch and his colleagues have demonstrated that intravenous injection of IGF-I purified from human serum or synthesized by recombinant DNA techniques reduced blood glucose and stimulated glycogen synthesis in normal or hypophysectomized rats given serum containing anti-insulin antibodies (14). Recombinant human IGF-I has also been demonstrated to produce a rapid hypoglycemic effect in healthy human subjects, much like insulin (15). These studies, however, have not elucidated the mechanisms underlying IGF-I's glucose lowering action; namely, whether IGF-I, like insulin, lowers blood glucose levels by both decreasing hepatic glucose production and increasing glucose uptake (16).

The chronic growth promoting effects of crude preparations of IGF-I in rats (17) have recently been reproduced with chronic infusions of recombinant human IGF-I in both hypophysectomized and insulin-deficient diabetic rats $(18,19)$. These findings imply that IGF-I may exert protein anabolic effects, a view supported by IGF-I's stimulatory effect on protein metabolism in vitro (7). However, it is unclear whether such effects $(a)$ require chronic hormone administration or $(b)$ would occur in mature animals that are neither growth hormone nor insulin-deficient.

The present study was undertaken to examine the acute effects of recombinant human IGF-I upon glucose and amino acid metabolism in awake, 24-h fasted mature rats. For this purpose, a combined infusion of $\left[3-{ }^{3} \mathrm{H}\right]$ glucose and $\left[1-{ }^{14} \mathrm{C}\right]-$ leucine was used to measure the rates of turnover of these substrates as well as their incorporation into tissue glycogen and protein, respectively. These experiments allowed us to $(a)$ compare the mechanism of IGF-I's hypoglycemic action with that of insulin and $(b)$ to determine whether IGF-I, like insulin, has immediate effects on amino acid metabolism, and if so, the extent to which such effects are mediated by changes in protein breakdown and/or synthesis. 


\section{Methods}

Animal preparation. Male Sprague-Dawley rats weighing 300-350 g had polyethylene catheters placed in a carotid artery and jugular vein 2 wk before study. The free ends of the catheters were exteriorized in the posterior cervical region, filled with a mixture of polyvinylpyrillidone $(1.7 \mathrm{~g} / \mathrm{ml}$, Sigma Chemical Co., St. Louis, MO) and heparin $(42 \mathrm{U} / \mathrm{ml})$, and capped. Animals were allowed to feed ad libitum during a $\sim 2$-wk recovery period. Only those rats that gained weight normally and showed no signs of infection were studied. Each animal was fasted for a period of $24 \mathrm{~h}$ before study. On the morning of the experiment, with the animals fully awake and freely moving about in their cages, the catheters were flushed with normal saline and maintained patent by a slow infusion $(\sim 20 \mu \mathrm{l} / \mathrm{min})$ of saline with dilute heparin $(1-2 \mathrm{U} / \mathrm{ml})$.

Procedures. Each animal received a primed $(9 \mu \mathrm{Ci})$ continuous $(0.14 \mu \mathrm{Ci} / \mathrm{min})$ infusion of both $\left[3-{ }^{3} \mathrm{H}\right] \mathrm{glucose}$ and $\mathrm{L}-\left[1-{ }^{14} \mathrm{C}\right]$ leucine for $180 \mathrm{~min}$. After a $90-\mathrm{min}$ tracer equilibration period, animals were assigned to one of four experimental protocols. Group $1(n=5)$ received only normal saline and served as the control group. Group 2 ( $n$ $=5$ ) received recombinant human (Thr 59) IGF-I (20) administered as a $250-\mu \mathrm{g} / \mathrm{kg}$ bolus followed by a $5-\mu \mathrm{g} / \mathrm{kg} \cdot \min$ continuous infusion for 90 min. Group $3(n=6)$ was given an identical primed-continuous IGF-I infusion; however, plasma glucose was maintained at baseline concentrations throughout using a variable rate infusion of $20 \%$ dextrose that was adjusted at 5-min intervals (21). The fourth group ( $n$ $=6$ ) received a primed-continuous infusion of regular porcine insulin for a total of $90 \mathrm{~min}$. The priming dose was given over the initial 10 min of the experiment at twice the continuous infusion rate. The continuous infusion rate was $1.4 \mathrm{mU} / \mathrm{min} \cdot \mathrm{kg}$. Throughout, plasma glucose was maintained at baseline levels using the same glucose clamp procedure (21) employed during IGF-I administration (group 3). This dose of insulin was found during preliminary experiments to stimulate whole body glucose uptake to a similar extent as did IGF-I under euglycemic conditions.

Plasma samples for glucose, $\left[{ }^{3} \mathrm{H}\right]$ glucose specific activity, amino acids, $\left[{ }^{14} \mathrm{C}\right]$ leucine specific activity, and IGF-I concentration were obtained at 15 -min intervals during the last $30 \mathrm{~min}$ of the equilibration period and during the experimental period at times indicated in Results. Additional plasma samples for measurement of insulin, lactate, and free fatty acids were obtained immediately before and during the last $30 \mathrm{~min}$ of each infusion protocol. The total volume of blood removed from each rat over the 3-h study did not exceed $4 \mathrm{ml}$ and the total volume infused over this time was 6-7 ml. At the end of the 180-min infusion period, the rats were killed by intravenous pentobarbital, the abdomen and chest were rapidly opened, and $\sim 1 \mathrm{~g}$ pieces of liver, rectus muscle, and heart were excised. The tissues were rapidly freeze-clamped and stored at $-70^{\circ} \mathrm{C}$ for later analysis.

Analytical methods. Plasma glucose was measured using a glucose analyzer (Yellow Springs Instrument Co., Yellow Springs, $\mathrm{OH}$ ), and $\left[3-{ }^{3} \mathrm{H}\right]$ glucose radioactivity was determined by a modification of the Somogyi precipitation procedure, as previously described (22). Plasma concentrations of acidic and neutral amino acids were measured by cation-exchange chromatography using an automated amino acid analyzer (Dionex D-500, Dionex Corp., Sunnyvale, CA). $\left[1-{ }^{14} \mathrm{C}\right]$ leucine was separated from bicarbonate and $\alpha$-ketoisocaproate (KIC) using Dowex 50W cation exchange resin (Dow Corning Corp., Midland, MI). Plasma free fatty acid concentrations were assayed using a modifcation of the Dole extraction procedure (23). Plasma lactate determinations were made using a lactate analyzer (Yellow Springs Instrument Co., Inc.). Plasma insulin levels were determined with a double antibody radioimmunoassay method (24); rat insulin standards were used except for samples obtained during infusions of exogenous porcine insulin which were analyzed with a porcine insulin standard. Samples for total plasma IGF-I (bound and free) were acid ethanol extracted and measured by a double antibody radioimmunoassay (25) using (Thr 59) IGF-I as the standard and ${ }^{125} \mathrm{I}(\mathrm{Thr} 59)$ IGF-I (Amersham Corp., Arlington Heights, IL) as the radioactive competitor. A rabbit anti-human IGF-I polyclonal antibody (lot A56), which recognizes human and rat IGF-I equally, was generously provided by Drs. J. Van Wyk and L. Underwood, University of North Carolina, Chapel Hill, NC.

Glycogen was extracted and purified from carefully weighed frozen samples of heart, liver and skeletal muscle as described by Waalas and Waalas (26). Extracted glycogen was subsequently hydrolyzed to glucose (27) and then measured by the glucose oxidase method. Radioactivity present in the purified glycogen was measured in a liquid scintillation system; quenching was corrected for with an external standard. Protein was purified from additional pieces of the frozen heart, liver and skeletal muscle tissues, as described by Morgan et al. (28). $1-{ }^{14} \mathrm{C}$ radioactivity was assayed from $10-\mathrm{mg}$ samples of purified tissue protein to determine the incorporation of labeled leucine radioactivity into protein.

Calculations. The basal fluxes of glucose and leucine were calculated by dividing the tracer infusion rate by the mean of three measurements of substrate specific activity obtained during the last $30 \mathrm{~min}$ of the equilibration period. During the experimental infusion period, the rates of endogenous glucose production and total body glucose uptake were estimated using a two-compartment model of glucose kinetics, described elsewhere (29). In those studies in which the glucose clamp technique was utilized, the rate of endogenous glucose production was calculated by subtracting the rate of exogenous glucose infusion during the last $30 \mathrm{~min}$ of the study from the rate of glucose production determined from the tracer data. For leucine, since no accepted nonsteady-state model exists, flux was estimated only in the basal period and during the last $30 \mathrm{~min}$ of the experimental infusion period when plasma leucine specific activity approached a new steady state (coeffcient of variation $<10 \%$ over the sampling period). At steady state the flux of leucine into and out of plasma reflects protein breakdown and the sum of oxidative and protein synthetic processes, respectively. Since leucine oxidation $\left({ }^{14} \mathrm{CO}_{2}\right.$ production) was not measured in the current study, leucine flux rates could not be used to estimate protein synthesis; this was instead evaluated by determining the incorporation of $\left[{ }^{14} \mathrm{C}\right]$ leucine into tissue proteins (see below). In estimating leucine flux into plasma we used the specific activity of plasma leucine rather than $\alpha$-ketoisocaproate (KIC) to keep blood losses within acceptable limits. As a result, leucine flux rates calculated from plasma leucine specific activity probably led to a small underestimation of rates of protein breakdown. Nevertheless, recent data suggest that the response of leucine flux to insulin infusion is qualitatively similar whether leucine or KIC specific activity is used (30). Leucine specific activity was also used (see below) to estimate the rate of tracer incorporation into tissue protein (an index of protein synthesis), as it is unclear whether plasma leucine or KIC specific activity more closely reflects the actual precursor pool for tissue protein synthesis (31).

Incorporation of ${ }^{3} \mathrm{H}$ and ${ }^{14} \mathrm{C}$ (derived from circulating glucose and leucine, respectively) during the study period was measured in tissue samples in all animals. The flux of these substrates from plasma into tissues during the experimental period was estimated by dividing the total disintegrations per minute in the purified tissue glycogen or protein samples by the mean plasma specific activity of the substrate during the experimental period.

All data are expressed as mean \pm SE. Data were analyzed using analysis of variance (ANOVA) (corrected for repeated measures when applicable). In addition, a two-tailed Student's $t$ test was done to localize time-points at which significant differences occurred.

\section{Results}

Effect of IGF-I and insulin on glucose metabolism. Infusion of IGF-I alone produced a nearly twofold increase above baseline $(P<0.05)$ in plasma IGF-I concentration (Fig. 1), whereas plasma insulin levels significantly declined (Table I). As shown in Fig. 1, plasma glucose rapidly decréased and remained $30-40 \mathrm{mg} / \mathrm{dl}$ below baseline values throughout the IGF-I infusion $(P<0.005)$. Hepatic glucose production $(4.3 \pm 0.3$ 

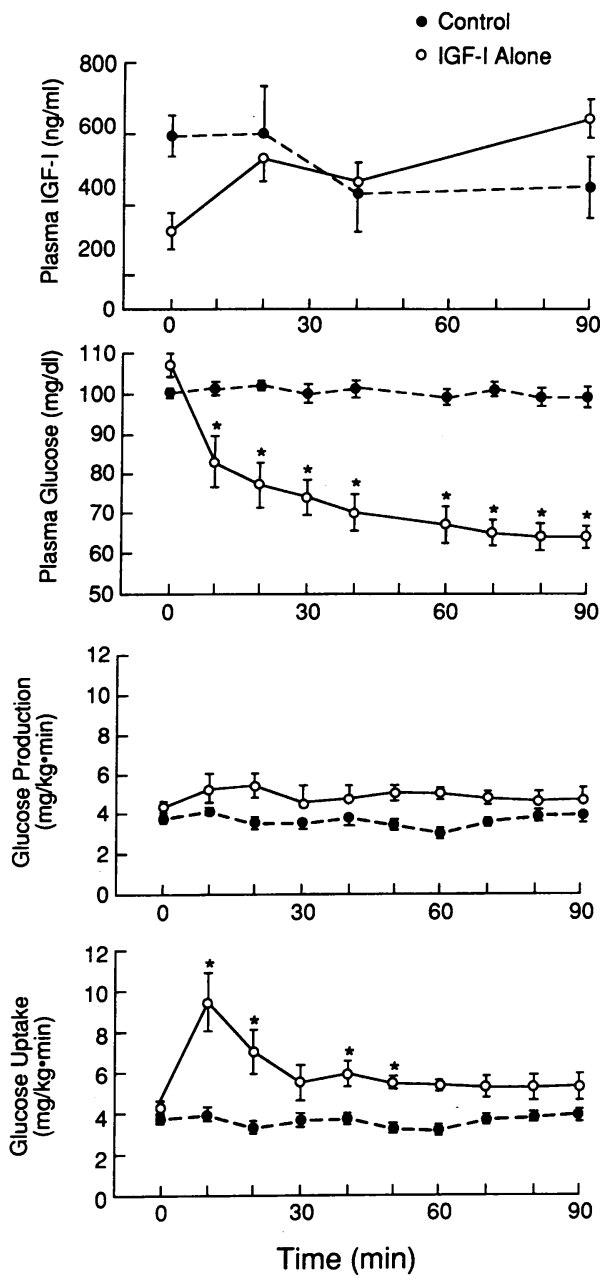

Figure 1. Circulating IGF-I levels, plasma glucose concentration, and glucose kinetics during IGF-I infusion (O) and saline control study (๑). Results are expressed as the mean \pm SE. ${ }^{*} P<0.05$ vs. saline control.

$\mathrm{mg} / \mathrm{kg} \cdot \mathrm{min}$, basal) did not change significantly. Instead, glucose uptake promptly increased (by $120 \%$ at $10 \mathrm{~min}, P<0.05$ ), later returning to baseline as plasma glucose concentration declined. In contrast, plasma glucose and glucose flux rates remained constant during saline infusion.

When IGF-I was infused while maintaining plasma glucose at baseline (coefficient of variation $<5 \%$ ), plasma IGF-I increased by $120 \%$ and insulin concentration again declined (Table I). As shown in Fig. 2, glucose uptake increased twofold, an effect that persisted throughout the entire 90-min infusion period. In contrast, hepatic glucose production $(4.8 \pm 0.4$ $\mathrm{mg} / \mathrm{kg} \cdot \mathrm{min}$, basal) was not significantly affected $(4.4 \pm 0.7$ $\mathrm{mg} / \mathrm{kg} \cdot \mathrm{min}$ at $60-90 \mathrm{~min}$ ), even though hypoglycemia was prevented. Table II shows the effect of IGF-I on the incorporation of $\left[3-{ }^{3} \mathrm{H}\right]$ glucose into tissue glycogen. IGF-I produced a marked stimulation of net glycogen synthesis in skeletal muscle, heart, and liver $(P<0.05$ vs. saline infusion).

Infusion of insulin produced a ninefold increase in circulating insulin levels, but no significant change in IGF-I concentration (Table I). Plasma glucose concentration was maintained at baseline values that were not significantly different from those achieved during the IGF-I clamp study. As shown in Fig. 2, glucose uptake increased twofold; a response indistinguishable from that observed during infusion of IGF-I. However, insulin markedly suppressed hepatic glucose production (from $4.1 \pm 0.2$ to $1.4 \pm 2 \mathrm{mg} / \mathrm{kg} \cdot \mathrm{min}, P<0.001$ ) in distinct contrast to IGF-I. On the other hand, insulin was significantly less effective than IGF-I in stimulating incorporation of labeled glucose into liver and heart tissue glycogen $(P$ $<0.05$ ); insulin failed to increase net glycogen synthesis in liver, heart or skeletal muscle over saline control values (Table II).

Plasma FFA concentrations before and at the end of the IGF-I and insulin infusions are shown in Table I. Infusion of IGF-I had no significant effect on plasma FFA concentrations as compared with either basal or saline control values, regardless of whether or not hypoglycemia was prevented. In contrast, insulin infusion suppressed circulating FFA levels by $40 \%(P<0.001)$. Plasma lactate rose similarly when IGF-I and insulin were administered under euglycemic conditions, but was unchanged during the saline control study (Table I).

Effect of IGF-I and insulin on amino acid metabolism. IGF-I infusion produced a $30-40 \%$ reduction in total amino acid concentration that was similar whether or not euglycemia was maintained (Table I). This effect extended to virtually all amino acids measured (Table III) and did not occur during the saline control study. The response to IGF-I was rapid and appeared to be near-maximal after $60 \mathrm{~min}$, as illustrated by plasma leucine which declined to levels $35-45 \%$ below baseline between 60 and 90 min $(P<0.01)$ (Fig. 3). The concentration of $\left[1-{ }^{14} \mathrm{C}\right]$ leucine was not, however, significantly af-

Table I. Effect of IGF-I and Insulin Infusion on Substrate and Hormone Concentrations in the Fasted Rat

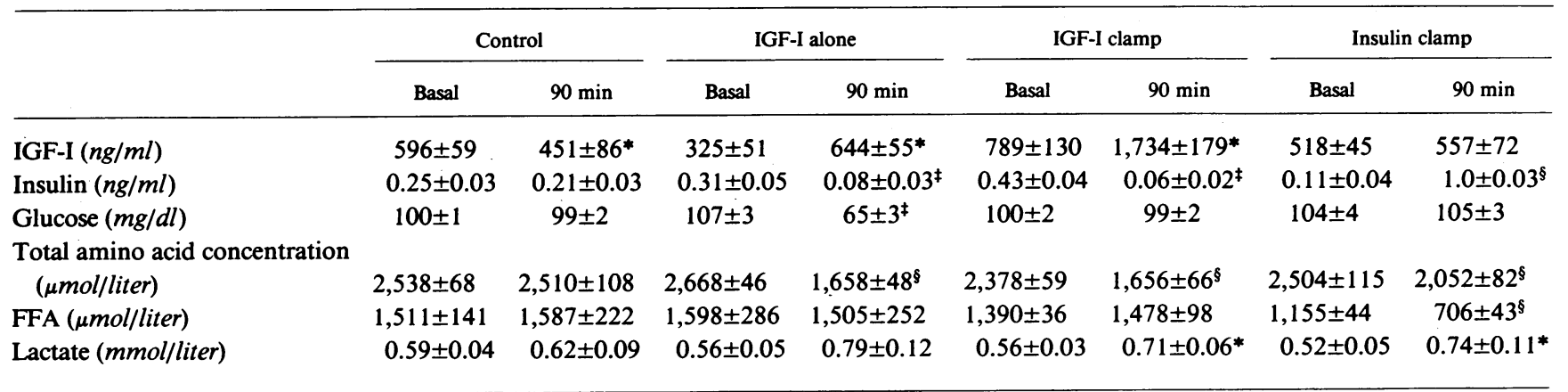

Values are means \pm SE. $P$ values are given for measurements showing a significant difference from basal by analysis of variance: ${ }^{*} P<0.05 ;{ }^{\ddagger} P$ $<0.01 ;{ }^{\S} P<0.001$. 

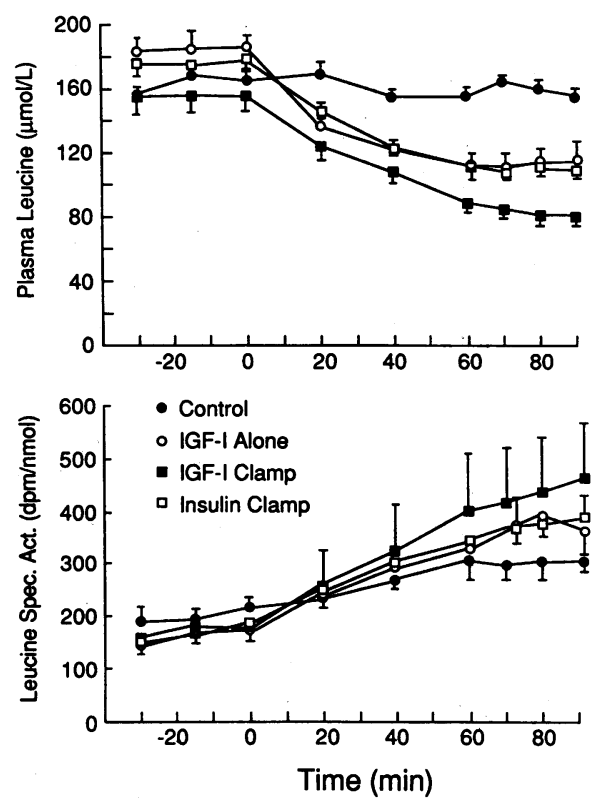

Figure 2. Effect of IGF-I and insulin on circulating leucine concentrations (upper panel) and plasma $\left[{ }^{14} \mathrm{C}\right]$ leucine specific activity (lower panel). Results are presented for each experimental protocol as fol-

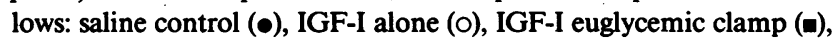
insulin euglycemic clamp (ם). Data are mean \pm SE.

fected during either of the two IGF-I protocols when compared to the saline control study. As a result, leucine specific activity rose more sharply during both IGF-I studies than during infusion of saline $(P<0.05)$ (Fig. 3).

Table IV demonstrates the effects of IGF-I on estimated rates of leucine flux. Infusion of IGF-I produced a twofold greater decline in leucine flux than was observed during saline infusion. The suppressive effect of IGF-I on leucine flux was not significantly different regardless of whether or not euglycemia was maintained. In keeping with these findings, the rate of incorporation of labeled leucine into tissue protein not only failed to increase, it actually decreased significantly during IGF-I infusion as compared to saline control values (Table V).

Infusion of insulin produced a similar, albeit slightly less pronounced decline in circulating amino acids as compared to

Table II. Effects of IGF-I and Insulin on Tracer-based Estimates of Glycogen Synthesis

\begin{tabular}{llcc}
\hline & \multicolumn{3}{c}{$\left[{ }^{3} \mathrm{H}\right]$ Glucose in glycogen } \\
\cline { 2 - 4 } & \multicolumn{1}{c}{ Liver } & Heart & Skeletal muscle \\
\hline & & $\mu \mathrm{mol} / \mathrm{g} \cdot 3 \mathrm{~h}$ \\
Control & $0.47 \pm 0.06$ & $0.64 \pm 0.13$ & $0.21 \pm 0.04$ \\
IGF-I clamp & $1.53 \pm 0.20^{*}$ & $1.85 \pm 0.41^{*}$ & $0.91 \pm 0.20^{*}$ \\
Insulin clamp & $0.29 \pm 0.06$ & $0.24 \pm 0.06^{*}$ & $0.41 \pm 0.08$
\end{tabular}

Values represent the incorporation of labeled glucose from plasma into tissue glycogen during the $3 \mathrm{~h}$ infusion of tracer. Data are presented as mean $\pm \mathrm{SE} .{ }^{*} P<0.05$ as compared to the saline control study.
IGF-I, except for the absence of any reduction in circulating alanine (Table I and III). Insulin also induced changes in plasma leucine and leucine specific activity that were not significantly different from those seen with IGF-I. Leucine flux declined significantly compared with saline infusion, a change that was indistinguishable from that observed during infusion of IGF-I (Table IV). Moreover, insulin (like IGF-I) led to a decline in the incorporation of labeled leucine into tissue protein (Table V).

\section{Discussion}

The current observations define the acute in vivo effects of recombinant IGF-I on glucose kinetics and on plasma amino acid metabolism. In addition, they provide the opportunity to compare the actions of IGF-I with those of insulin when given in doses that produce an equivalent stimulation of glucose metabolism. Our data demonstrate that IGF-I has potent stimulatory effects on glucose disposal, causes generalized hypoaminoacidemia, and inhibits the rate of leucine appearance into plasma. These insulin-like effects must be attributed to IGF-I per se, since circulating insulin levels declined during IGF-I infusion.

Although the effects of IGF-I in some cases were indistinguishable from insulin, there were a number of instances where substantial differences were evident. Considering first glucose disposal, both IGF-I and insulin at the doses used provoked comparable, sustained increases in glucose uptake in the fasted rat when euglycemia was maintained. This effect of IGF-I was transient when glucose was allowed to fall, presumably due to the fall in glucose concentration itself and the concomitant release of counterregulatory hormones (32). It is noteworthy that, on a molar basis, the dose of insulin was only $1-2 \%$ of that for IGF-I. This is in keeping with previous reports indicating that insulin is a more potent hypoglycemic agent than IGF-I in vivo $(13,15,33)$.

Previous studies have demonstrated that the principal site of enhanced glucose uptake during euglycemic hyperinsulinemia is muscle tissue (34). This may also be the case for IGF-I. IGF-I infusion markedly increased glycogen synthesis in heart and skeletal muscle, a finding consistent with earlier reports by Froesch and co-workers showing IGF-I to be a potent stimulator of glucose uptake (4) and glycogen synthesis (14) in skeletal muscle. The liver also demonstrated an increase in glycogen synthesis with IGF-I infusion, implying that tissues other than muscle may have participated in IGF-I's enhancement of glucose disposal. Interestingly, although increases in glucose disposal were essentially identical with IGF-I or insulin, only IGF-I significantly increased glucose incorporation into tissue glycogen (Table II). Although we have no definitive explanation for this difference, it may be related to the fact that only insulin suppressed circulating FFA, the primary respiratory fuel for both heart and skeletal muscle. By reducing the availability of FFA, insulin may have directed glucose metabolism toward oxidation (35), thereby diminishing the rate of glycogen formation as compared with IGF-I. Such differences in tissue glucose handling might not be evident at higher rates of insulin infusion that increase tissue glucose utilization to a greater extent, since under these conditions insulin clearly promotes glucose storage as glycogen (36).

Although IGF-I and insulin had similar effects on glucose uptake, their action on hepatic glucose production was strik- 
Table III. Effect of IGF-I and Insulin Infusion on Concentrations of Individual Amino Acids

\begin{tabular}{|c|c|c|c|c|c|c|c|c|}
\hline \multirow[b]{2}{*}{ Amino acid } & \multicolumn{2}{|c|}{ Control } & \multicolumn{2}{|c|}{ IGF-I alone } & \multicolumn{2}{|c|}{ IGF-I clamp } & \multicolumn{2}{|c|}{ Insulin clamp } \\
\hline & Basal & $60-90 \mathrm{~min}$ & Basal & $60-90 \mathrm{~min}$ & Basal & $60-90 \mathrm{~min}$ & Basal & $60-90 \mathrm{~min}$ \\
\hline & \multicolumn{8}{|c|}{ umol/liter } \\
\hline Thr & $269 \pm 17$ & $280 \pm 21$ & $266 \pm 13$ & $169 \pm 7^{\ddagger}$ & $241 \pm 14$ & $155 \pm 7^{\S}$ & $289 \pm 16$ & $245 \pm 14^{\S}$ \\
\hline Ser & $226 \pm 10$ & $238 \pm 13$ & $256 \pm 10$ & $159 \pm 9^{\S}$ & $205 \pm 12$ & $149 \pm 8^{\S}$ & $260 \pm 14$ & $226 \pm 13^{\ddagger}$ \\
\hline Asn & $59 \pm 3$ & $61 \pm 4$ & $61 \pm 2$ & $34 \pm 3^{\S}$ & $50 \pm 2$ & $31 \pm 1^{\S}$ & $58 \pm 4$ & $49 \pm 3^{\ddagger}$ \\
\hline Glu & $87 \pm 8$ & $76 \pm 10$ & $77 \pm 8$ & $56 \pm 9$ & $104 \pm 6$ & $84 \pm 5$ & $94 \pm 8$ & $74 \pm 3^{*}$ \\
\hline Gln & $575 \pm 22$ & $550 \pm 34$ & $588 \pm 13$ & $362 \pm 10^{\S}$ & $551 \pm 27$ & $404 \pm 30^{\S}$ & $435 \pm 27$ & $352 \pm 18^{\S}$ \\
\hline Gly & $376 \pm 18$ & $403 \pm 22^{*}$ & $389 \pm 19$ & $264 \pm 8^{8}$ & $368 \pm 12$ & $280 \pm 11^{\S}$ & $382 \pm 21$ & $321 \pm 18^{\S}$ \\
\hline Ala & $274 \pm 17$ & $293 \pm 34$ & $278 \pm 12$ & $154 \pm 16^{\S}$ & $237 \pm 8$ & $192 \pm 11^{\ddagger}$ & $262 \pm 22$ & $268 \pm 17$ \\
\hline Val & $195 \pm 6$ & $198 \pm 8$ & $223 \pm 13$ & $155 \pm 11^{\ddagger}$ & $193 \pm 12$ & $122 \pm 7^{\S}$ & $221 \pm 14$ & $161 \pm 10^{\S}$ \\
\hline Ile & $97 \pm 3$ & $95 \pm 2$ & $110 \pm 6$ & $68 \pm 5^{\ddagger}$ & $96 \pm 8$ & $54 \pm 4^{\S}$ & $108 \pm 4$ & $67 \pm 4^{\S}$ \\
\hline Leu & $163 \pm 4$ & $159 \pm 4$ & $185 \pm 8$ & $113 \pm 7^{\ddagger}$ & $153 \pm 10$ & $84 \pm 6^{\S}$ & $175 \pm 6$ & $108 \pm 4^{\S}$ \\
\hline Tyr & $48 \pm 3$ & $47 \pm 5$ & $56 \pm 3$ & $40 \pm 2^{\ddagger}$ & $47 \pm 5$ & $31 \pm 3^{*}$ & $49 \pm 2$ & $46 \pm 3$ \\
\hline Phe & $71 \pm 4$ & $71 \pm 4$ & $72 \pm 2$ & $52 \pm 3^{\ddagger}$ & $64 \pm 2$ & $49 \pm 2^{\ddagger}$ & $70 \pm 3$ & $65 \pm 3$ \\
\hline
\end{tabular}

Results are presented as mean \pm SE. Basal values represent the mean of three samples obtained over a 30-min period whereas the values at 60-90 min are the mean of four samples obtained at 10-min intervals over that time period. Those amino acids showing a significant change from basal (ANOVA) are indicated as follows: ${ }^{*} P<0.05 ;{ }^{\ddagger} P<0.01 ;{ }^{\S} P<0.001$.

ingly different. Despite the relatively larger dose of IGF-I, insulin but not IGF-I, suppressed glucose production. As a result, the hypoglycemic action of IGF-I could be entirely explained by its effects on glucose disposal, whereas insulin acted by simultaneously increasing disposal and decreasing the production of glucose. It should be emphasized, however, that the apparent insensitivity of hepatic glucose production to IGF-I may be a relative phenomenon, since dose-response relationships were not examined. Furthermore, these studies were performed in 24-h fasted rats that were undoubtedly dependent on gluconeogenesis for the maintenance of glucose production. Consequently, our data do not exclude an inhibitory effect of IGF-I on glucose production under conditions where glycogenolysis has a more important role. Although the mechanism(s) responsible for the disparate response of glucose pro-
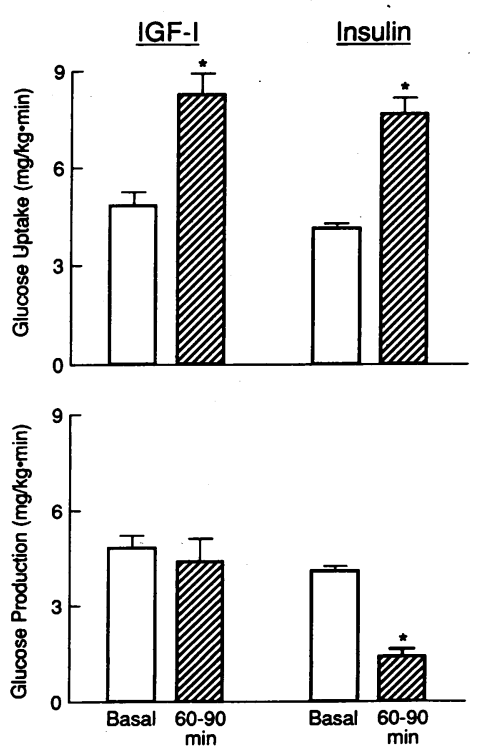

Figure 3. Comparison of effects of IGF-I and insulin on total body glucose uptake (upper panel) and hepatic glucose production (lower panel) during euglycemic clamp study. The bars (mean $\pm \mathrm{SE})$ denote values in the basal state and during the last $30 \mathrm{~min}$ of each infusion study. ${ }^{*} P$ $<0.001$ vs. basal value. duction to IGF-I and insulin remains uncertain, this finding does not appear to be attributable to differences in the availability of either glycogenic amino acids (Table III) or lactate (Table I). Perhaps a relative deficiency of hepatic IGF-I receptors (37) or the stimulatory effects of FFA on hepatic gluconeogenesis (38) contribute to the diminished suppression of glucose production during IGF-I infusion. It may at first glance appear paradoxical that IGF-I did not affect gluconeogenesis, but still enhanced glycogen synthesis in liver. This could be explained if gluconeogenesis were less sensitive to inhibition by IGF-I than is glycogenolysis. Such a differential effect exists for insulin in man and the dog $(39,40)$.

Our inability to demonstrate a reduction in circulating FFA levels during IGF-I infusion constitutes an additional feature that distinguishes the actions of IGF-I from those of

Table IV. Changes in Plasma Leucine Flux Rate during IGF-I, Insulin, and Saline Infusion

\begin{tabular}{lccc}
\hline & \multicolumn{3}{c}{ Leucine flux } \\
\cline { 2 - 4 } & Basal & $60-90 \mathrm{~min}$ & $P$ \\
\hline & $\mu \mathrm{mol} / \mathrm{kg} \cdot \mathrm{min}$ & $\mu \mathrm{mol} / \mathrm{kg} \cdot \mathrm{min}$ & \\
Control & $2.95 \pm 0.25$ & $2.08 \pm 0.15$ & \\
IGF-I alone & $3.43 \pm 0.42$ & $1.60 \pm 0.32$ & $<0.005$ \\
IGF-I clamp & $3.09 \pm 0.40$ & $1.33 \pm 0.21$ & $<0.01$ \\
Insulin clamp & $2.80 \pm 0.30$ & $1.34 \pm 0.15$ & 0.057 \\
& & & \\
\hline
\end{tabular}

Values are expressed as the mean $\pm \mathrm{SE}$. Basal calculations are based on the last $30 \mathrm{~min}$ of the equilibration period. Leucine flux at the end of each infusion protocol was calculated from the mean of four measurements obtained between 60 and $90 \mathrm{~min}$. Analysis of variance showed that the response among the experimental groups was significantly different. $P$ values represent the significance of response to treatment as compared to the saline control study as determined by post hoc $t$ test. 
Table V. Effects of IGF-I and Insulin on Tracer-based Estimates of Protein Synthesis

\begin{tabular}{lccc}
\hline & \multicolumn{3}{c}{$\left[{ }^{14} \mathrm{C}\right]$ Leucine in protein } \\
\cline { 2 - 4 } & \multicolumn{1}{c}{ Liver } & Heart & Skeletal muscle \\
\hline & & $\mu \mathrm{mol} / \mathrm{g} \cdot 3 \mathrm{~h}$ \\
Control & $2.01 \pm 0.21$ & $0.60 \pm 0.07$ & $0.34 \pm 0.09$ \\
IGF-I clamp & $1.17 \pm 0.16^{*}$ & $0.37 \pm 0.04^{*}$ & $0.12 \pm 0.02^{*}$ \\
Insulin clamp & $1.29 \pm 0.18^{*}$ & $0.38 \pm 0.04^{*}$ & $0.13 \pm 0.01^{*}$ \\
\hline
\end{tabular}

Values represent the incorporation of labeled leucine from plasma into tissue protein during the $3 \mathrm{~h}$ infusion of tracer. Data are presented as mean \pm SE. ${ }^{*} P<0.05$ as compared to the saline control study.

insulin. This finding is consistent with earlier studies in the rat (14). Guller et al. (15) also reported that doses of IGF-I that produce hypoglycemia in man only minimally affect plasma FFA. The lack of effect of IGF-I on FFA levels may have been simply a consequence of the dose of IGF-I used. In vitro studies suggest that IGF-I does not act on adipose tissue though its own receptor, but rather through its capacity to weakly bind to the insulin receptor $(8,9,11,41)$.

In contrast to glucose production and FFA concentration, IGF-I's effects on plasma amino acids, leucine kinetics, and leucine incorporation into protein closely resemble those seen with insulin. IGF-I, like insulin, caused generalized hypoaminoacidemia and accelerated the rise in plasma leucine specific activity compared with saline, presumably as a result of an inhibition of tissue protein degradation. The slow rise in plasma leucine specific activity in the saline-infused rats is likely due to conservation of body protein during more prolonged fasting, recycling of label, or both (42). Since plasma leucine appeared to be near steady state at the end of the equilibration period and over the last $30 \mathrm{~min}$ of the experimental period, we used the steady-state assumption to estimate the leucine flux. Regardless of the potential quantitative errors introduced by this approach, it is clear that at least from a qualitative standpoint, leucine flux fell to a significantly greater extent in both the IGF-I and the insulin infused rats when compared to control animals. A decrease in leucine flux has also been reported during euglycemic hyperinsulinemia in the dog and man $(43,44)$. The observed decline in labeled leucine incorporation into heart, skeletal muscle, and liver protein together with the fall in total leucine flux suggests that the amino acid lowering effect of both insulin and IGF-I results from a diminution of the rate of protein degradation rather than an increase in protein synthesis in the fasted rat.

The extent to which our results represent a physiologic effect of IGF-I is difficult to resolve. Although we observed only a twofold rise in IGF-I concentration, a greater increment in the free concentration presumably occurred. Nevertheless, the changes in total IGF-I immunoreactivity produced during this study are similar to those reported in humans after injection of growth hormone (45). A second closely related issue is whether the effects of IGF-I on glucose uptake and amino acid metabolism are due to IGF-I acting through its own specific receptor or whether they are attributable to binding to the insulin receptor. The latter explanation is less likely consider- ing the apparent lack of effect of IGF-I on glucose production and fatty acid mobilization, processes more sensitive to insulin than glucose uptake $(16,46)$.

Our results provide a clear demonstration that IGF-I administration exerts potent effects on protein metabolism in the mature rat that is neither rapidly growing nor growth hormone-deficient. The prompt inhibitory effect of IGF-I on proteolysis was demonstrable in 24-h fasted animals that were undoubtedly in significant negative nitrogen balance (47). If this action of IGF-I extends to other protein wasting states (e.g., burns or trauma [48]), IGF-I administration may be useful therapeutically.

\section{Acknowledgments}

The assistance of Ms. Judie King in the analysis of samples for tracer incorporated in tissue glycogen and proteins is gratefully acknowledged. We also wish to thank Dr. Mary Peters and Steven Finley (AMGen Boulder, Inc) for preparation of the recombinant IGF-I and Ms. Aida Grozmann for the measurement of plasma insulin. The invaluable assistance of Nancy Canetti in the preparation of the manuscript is also sincerely appreciated.

This research was supported in part by grants from the National Institutes of Health (AM-20495), the American Heart Foundation (AHA870328), and the Deutsche Forschungsgemeinschaft.

\section{References}

1. Daughday, W. H., K. Hall, M. S. Raben, W. D. Salmon, Jr., J. L. Van den Brande, and J. J. Van Wyk. 1972. Somatomedin: proposed designation for sulphation factor. Nature (Lond.). 235:207.

2. Meuli, C., and E. R. Froesch. 1977. Insulin and non suppressible insulin-like activity (NSILAs) stimulated the same glucose transport system via two separate receptors in rat heart. Biochem. Biophys. Res. Commun. 75:689-695.

3. Zapf, J., E. Schoenle, and E. R. Froesch. 1978. Insulin-like growth factors I and II. some biological actions and receptor binding characteristics of two purified constituents of non suppressible insulin-like activity of human serum. Eur. J. Biochem. 87:285-296.

4. Poggi, C., Y. Le Marchand-Brustel, J. Zapf, E. R. Froesch, and P. Freychet. 1979. Effects of binding of insulin-like growth factor I in the isolated soleus muscle of lean and obese mice: comparison with insulin. Endocrinology. 105:723-730.

5. Zapf, J., E. R. Froesch, and R. E. Humbel. 1981. The insulin-like growth factors (GF) of human serum: Chemical and biological characterization and aspects of their possible physiological role. Curr. Top. Cell. Regul. 19:257-309.

6. Rechler, M. M., S. P. Nissley, G. L. King, A. C. Moses, E. E. Van Obberghen-Schilling, J. A. Romanus, A. B. Knight, P. A. Short, and R. M. White. 1981. Multiplication stimulating activity (MSA) from BRL3A rat liver line: Relation to human somatomedins and insulin. $J$. Supramol. Struct. Cell Biochem. 15:253-286.

7. Guenther, H. L., H. E. Guenther, E. R. Froesch, and H. Fleisch. 1982. Effect of insulin-like growth factor on collagen and glycosaminoglycan synthesis by rabbit articular chondrocytes in culture. Experientia (Basel). 38:979-980.

8. King, G. L., C. R. Kahn, M. M. Rechler, and S. P. Hissley. 1980. Direct demonstration of separate receptors for growth and metabolic activities of insulin and multiplication-stimulating activity (an insulin-like growth factor) using antibodies to the insulin receptor. J. Clin. Invest. 66:130-140.

9. Zapf, J., E. Schoenle, M. Waldvogel, I. Sand, and E. R. Froesch. 1981. Effect of trypsin treatment of rat adipocytes on biological effects and binding of insulin and insulin-like growth factors. Further evidence for the action of insulin-like growth factors through the insulin receptor. Eur. J. Biochem. 113:605-609. 
10. Yo, K. T., and M. P. Czech. 1984. The type 1 insulin-like growth factor receptor mediates the rapid effects of multiplication stimulating activity on membrane transport systems in rat soleus muscle. J. Biol. Chem. 259:3090-3095.

11. Bolinder, J., A. Lindblad, P. Engfeldt, and P. Arner. 1987. Studies of acute effects of insulin-like growth factors I and II in human fat cells. J. Clin. Endocrinol. Metab. 65:732-737.

12. Froesch, E. R., W. A. Muller, H. Burgi, M. Waldvogel, and A. Labhart. 1966. Nonsuppressible insulin-like activity of human serum. II. Biological properties of plasma extracts with non-suppressible insulin-like activity. Biochim. Biophys. Acta. 121:360-374.

13. Delz, O., A. Jakob, and E. R. Froesch. 1970. Nonsuppressible insulin-like activity (NSILA) of human serum. V. Hypoglycemia and preferential metabolic stimulation of muscle by NSILA-s. Eur. J. Clin. Invest. 3:48-53.

14. Zapf, J., C. Hauri, M. Waldvogel, and E. R. Froesch. 1986. Acute metabolic effects and half-lives of intravenously administered insulin-like growth factors I and II in normal and hypophysectomized rats. J. Clin. Invest. 77:1768-1775.

15. Guller, H. P., J. Zapf, and E. R. Froesch. 1987. Short-term metabolic effects of recombinant human insulin-like growth factor $I$ in healthy adults. N. Engl. J. Med. 317:137-140.

16. Rizza, R., L. Mandarino, and J. Gerich. 1981. Dose-response characteristics for effects of insulin on production and utilization of glucose in man. Am. J. Physiol. 240:E630-E639.

17. Van Buul-Offers, S., and J. L. Van den Brande. 1979. Effect of growth hormone and peptide fractions containing somatomedin activity on growth and cartilage metabolism of Snell Dwarf mice. Acta Endocrinol. 92:242-257.

18. Schoenle, E., J. Zapf, R. E. Humbel, and E. R. Froesch. 1982. Insulin-like growth factor I stimulates growth in hypophysectomized rats. Nature (Lond.). 296:252-253.

19. Scheiwiller, E., H. P. Guller, J. Merriweather, C. Scandella, W. Maerki, J. Zapf, and E. R. Froesch. 1986. Growth restoration of insulin-deficient diabetic rats by recombinant human insulin-like growth factor I. Nature (Lond.). 323:169-171.

20. Peters, M. A., E. P. Lau, D. L. Snitman, J. J. Van Wyk, L. E. Underwood, W. E. Russell, and M. E. Svoboda. 1985. Expression of a biologically active analogue of somatomedin-C/insulin-like growth factor I. Gene. 35:83-89.

21. Smith, D., L. Rossetti, E. Ferrannini, C. M. Johnson, C. Cobelli, G. Toffalo, L. D. Katz and R. A. DeFronzo. 1987. In vivo glucose metabolism in the awake rat: tracer and insulin clamp studies. Metab. Clin. Exp. 36:1167-1174.

22. Ferrannini, E., R. A. DeFronzo, and R. S. Sherwin. 1982. Transient hepatic response to glucagon in man: role of insulin and hyperglycemia. Am. J. Physiol. 242:E73-E81.

23. Novak, N. 1965. Colorimetric ultramicro method for the determination of free fatty acids. J. Lipid Res. 6:431-433.

24. Morgan, C. R., and A. Lazarow. 1963. Immunoassay of insulin plasma insulin levels of normal, subdiabetic and diabetic rats. Dia betes. 12:115-126.

25. Furlanetto, R. W., L. E. Underwood, J. J. Van Wyk, and A. J. D'Ercole. 1977. Estimation of somatomedin-C levels in normals and patients with pituitary disease by radioimmunoassay. J. Clin. Invest. 60:648-657.

26. Walaas, O., and E. Walaas. 1950. Effect of epinephrine on rat diaphragm. J. Biol. Chem. 187:769-776.

27. Lust, W. D., J. V. Passoneau, and S. K. Crites. 1975. The measurement of glycogen in tissues by amylo- $\alpha-1,4-\alpha-1,6$-glucosidase after destruction of pre-existing glucose. Anal. Biochem. 68:328-331.

28. Morgan, E. H., D. Earl, A. Broadus, E. Wolpert, K. Giger, and L. S. Jefferson. 1971. Regulation of protein synthesis in heart muscle. I. Effects of amino acid levels on protein synthesis. J. Biol. Chem. 246:2152-2162.

29. Radziuk, J., K. H. Norwich, and M. Vranic. 1978. Experimental validation of measurements of glucose turnover in nonsteady state. Am. J. Physiol. 234:E84-E93.

30. Castellino, P., L. Luzi, D. C. Simonson, M. Haymond, and
R. A. DeFronzo. 1987. Effect of insulin and plasma amino acid concentrations on leucine metabolism in man: role of substrate availability on estimates of whole body protein synthesis. J. Clin. Invest. 80:1784-1793.

31. Martin, A. F., M. Rabinowitz, R. Blough, G. Prior, and R. Zak. 1977. Measurements of half-life of rat cardiac myosin heavy chain with leucyl-tRNA used as precursor pool. J. Biochem. 252:3422-3429.

32. Saccá, L., R. Sherwin, R. Hendler, and P. Felig. 1979. Influence of continuous physiological hyperinsulinemia on glucose kinetics and counter-regulatory hormones and diabetic humans. J. Clin. Invest. 63:849-857.

33. Wein Valliant, S., M. Peters, S. Finley, and K. Fagin. 1986. Hypoglycemic potency and pharmacokinetics in conscious rats. 68th Annual Meeting of the Endocrine Society, Anaheim, CA, p. 129. (Abstr.)

34. DeFronzo, R. A., E. Ferrannini, R. Hendler, J. Wahren, and P. Felig. 1978. Influence of hyperinsulinemia, hyperglycemia, and the route of glucose administration on splanchnic glucose exchange. Proc. Natl. Acad. Sci. USA. 75:5173-5177.

35. Kaijsen, L. 1980. Effect of metabolic intervention on substrate metabolism in the human heart. In Advances in Myocardiology. Volume 2. M. Tajaddin, B. Bhatia, H. Siddiqui, G. Rona, editors. University Park Press, Baltimore. 51-59.

36. Krusznska, Y. T., P. D. Home, and K. G. M. M. Alberti. 1986. In vivo regulation of liver and skeletal muscle glycogen synthase activity by glucose and insulin. Diabetes. 35:662-667.

37. Caro, J. F., J. Poulos, O. Ittoop, W. J. Pories, E. G. Flickinger, and M. K. Sinha. 1988. Insulin-like growth factor I binding from human liver, human hepatoma, and normal regenerating, and fetal rat liver. J. Clin. Invest. 81:976-981.

38. Williamson, J. R., R. A. Kreisberg, and P. W. Felts. 1966. Mechanism for the stimulation of gluconeogenesis by fatty acids in perfused rat liver. Proc. Natl. Acad. Sci. USA. 56:247-254.

39. Chiasson, J. L., R. L. Atkinson, A. D. Cherrington, U. Keller, B. C. Sinclair-Smith, W. W. Lacy, and J. E. Liljenquist. 1980. Effects of insulin at two dose levels on gluconeogenesis from alanine in fasting man. Metab. Clin. Exp. 29:810-818.

40. Chiasson, J. L., J. E. Liljenquist, and F. E. Fryer. 1976. Differential sensitivity of glycogenolysis and gluconeogenesis to insulin infusions in dogs. Diabetes. 25:283-291.

41. Clemmons, D. R., and J. J. Van Wyk. 1981. Somatomedin: physiological control and effects on cell proliferation. In Handbook of Experimental Pharmacology. R. Baserga, editor. Springer-Verlag, Berlin. 161-208.

42. Schwenk, W. F., E. Tsalikian, B. Beaufrere, and M. W. Haymond. 1985. Recycling of an amino acid label with prolonged isotope infusion: implications for kinetic studies. Am. J. Physiol. 248 (Endocrinol. Metab. 11):E482-487.

43. Abumrad, N. N., L. S. Jefferson, S. R. Rannels, P. E. Williams, A. D. Cherrington, and W. W. Lacy. 1982. Role of insulin in the regulation of leucine kinetics in the conscious dog. J. Clin. Invest. 70:1031-1041.

44. Fukagawa, N. K., K. L. Minaker, J. W. Rowe, M. N. Goodman, D. E. Mathews, D. M. Bier, and V. R. Young. 1985. Insulin-mediated reduction of whole body protein breakdown. J. Clin. Invest. 76:23062311.

45. Copeland, K. C., L. E. Underwood, and J. J. Van Wyk. 1980. Induction of immunoreactive somatomedin- $C$ in human serum by growth hormone: dose response relationships and effect on chromatographic profiles. J. Clin. Endocrinol. Metab. 50:690-697.

46. Zierler, K. L., and D. Rabinowitz. 1964. Effects of very small concentrations of insulin on forearm metabolism: persistence of its action on potassium and free fatty acids without its effect on glucose. $J$. Clin. Invest. 43:950-962.

47. Li, J. B., J. E. Higgins, and L. S. Jefferson. 1979. Changes in protein turnover in skeletal muscle in response to fasting. Am. J. Physiol. 236:E222-E228.

48. Aulick, L. H., and D. W. Wilmore. 1979. Increased peripheral amino acid release following burn injury. Surgery. 85:560-565. 